\title{
Taxonomy of Clostridium tetani and Related Species
}

\author{
By S. NAKAMURA, IMIKO OKADO, TOMO ABE AND S. NISHIDA \\ Department of Bacteriology, School of Medicine, Kanazawa University, \\ Kanazawa 920, Japan
}

(Received 7 December 1978)

\begin{abstract}
Clostridium tetani and its related species C. tetanomorphum, C. cochlearium and C. lentoputrescens were examined for DNA-DNA homology and biochemical properties. Two distinctly different groups were included under the name of $C$. tetanomorphum: one was identical with $C$. cochlearium and the name $C$. tetanomorphum was applied to the other group with some amendment of biochemical properties. Comparison of the type strain of $C$. lentoputrescens with wild strains obtained from horse faeces indicated that the name $C$. lentoputrescens should be abolished as a later synonym of $C$. cochlearium. Liquefaction of gelatin and spore shape, which have been used as the important criteria for differentiation of C. tetani-related species, were genetically insignificant.
\end{abstract}

\section{INTRODUCTION}

This study has investigated the relationships between Clostridium tetani-related species, i.e. C. tetani (Flügge) Bergey et al. 1923, C. cochlearium (Douglas, Fleming \& Colebrook) Bergey et al. 1923 and C. lentoputrescens Hartsell \& Rettger 1934. Bacillus tetanomorphum and Bacillus cochlearius were established in 1919 by Bulloch et al. (1919) and the genus name Clostridium was applied to them in the first edition of Bergey's Manual of Determinative Bacteriology (Bergey et al., 1923). Since then, the name $C$. tetanomorphum has appeared in the Manual up to the seventh edition (Breed et al., 1957) but has disappeared from the eighth edition (Smith \& Hobbs, 1974). Takahashi et al. (1967) have previously reported that two distinctly different groups were included under the name $C$. tetanomorphum. In the present study, tests for DNA-DNA homology, thermostability of DNA duplexes and biochemical properties were used to determine to which group the name of C. tetanomorphum should be applied. Furthermore, a possible identity of C. cochlearium and C. lentoputrescens has been re-investigated in the light of DNA-DNA homology determinations.

\section{METHODS}

Strains. These are listed, with the names as received, in Table 1. Strain K-130 was recovered from C. tetani HA-47 after heating at $100^{\circ} \mathrm{C}$ for $30 \mathrm{~min}$ (Nishida et al., 1969). Non-toxigenic strains M-2, M-6 and M-14 have all the characteristics of $C$. tetani except toxicity.

Preparation of DNA. Clostridium tetani HA-47, CN 655, 1110, 1113, 1303, 6114, 6116, PO5 and 007, and C. tetani-like strain $\mathrm{K}-130$ were grown at $37^{\circ} \mathrm{C}$ in THPYG medium (pH 7.2) containing ( $\%$, w/v): trypticase (BBL), 0.5 ; heart infusion broth (Nissui, Tokyo, Japan), 0.5 ; polipeptone (Daigo, Osaka, Japan), 1.0; yeast extract (Daigo), 1.0; glucose, $1 \cdot 0 ; \mathrm{NaCl}, 0 \cdot 5 ; \mathrm{L}$-cysteine. $\mathrm{HCl}, 0 \cdot 05$. Clostridium tetani $\mathrm{M}-20, C$. tetanomorphum 500 and 543, C. lentoputrescens 17794 and C. tetani-like strains M-2, M-6 and M-14 were grown in PYG medium ( $\mathrm{pH} 7 \cdot 2)$ containing ( $\%, \mathrm{w} / \mathrm{v})$ : polipeptone (Daigo), $2 \cdot 0$; yeast extract (Daigo), 1.0; glucose, $1.0 ; \mathrm{NaCl}, 0.5 ; \mathrm{L}$-cysteine. $\mathrm{HCl}, 0.05$. Penicillin $\mathrm{G}\left(50 \mu \mathrm{g} \mathrm{ml}^{-1}\right)$ was added in the late-exponential phase of growth and cultures were incubated for a further 30 to $45 \mathrm{~min}$ at $37^{\circ} \mathrm{C}$. The organisms were then harvested by centrifugation, resuspended in $0.15 \mathrm{M}-\mathrm{NaCl} / 0.01 \mathrm{M}$-EDTA at $\mathrm{pH} 8.0$ and lysed with $3 \%(\mathrm{w} / \mathrm{v})$ sodium dodecyl sulphate (SDS). Bacterial suspensions of strains 543 and 17794 in $\mathrm{NaCl} / \mathrm{EDTA}$ solution were heated 


\section{Table 1. Source and designation of bacterial strains}

\begin{tabular}{|c|c|c|}
\hline Name (as received) & Strain designation & Source \\
\hline Clostridium tetani & $\begin{array}{l}\text { Havard A-47 (HA-47) } \\
\text { CN } 655 \\
1110,1113,1303,6114,6116 \\
\text { PO5, 007, M-20 }\end{array}$ & $\begin{array}{l}\text { M. Yoneda* } \\
\text { Pasteur Institute (Paris) } \\
\text { Stock strains (Sanada \& } \\
\text { Nishida, 1965) } \\
\text { Stock strains }\end{array}$ \\
\hline C. cochlearium & $\begin{array}{l}17787 \\
\text { montréan }\end{array}$ & $\begin{array}{l}\text { ATCC. Type strain } \\
\text { Pasteur Institute (Paris) }\end{array}$ \\
\hline C. lentoputrescens & 17794 & ATCC. Type strain \\
\hline C. tetanomorphum & $\begin{array}{l}1772 \text { C, CIA, A } \\
2909,288,500,543\end{array}$ & $\begin{array}{l}\text { Pasteur Institute (Paris) } \\
\text { NCTC }\end{array}$ \\
\hline C. tetani-like strains & $\begin{array}{l}\mathrm{K}-130 \\
\mathrm{M}-2, \mathrm{M}-6, \mathrm{M}-14\end{array}$ & $\begin{array}{l}\text { Stock strain (Nishida et al., } \\
\text { 1969) } \\
\text { Stock strains }\end{array}$ \\
\hline
\end{tabular}

at $60{ }^{\circ} \mathrm{C}$ for $20 \mathrm{~min}$, before treatment with $1 \mathrm{mg}$ lysozyme $\mathrm{ml}^{-1}$ (Seikagaku, Tokyo, Japan) and $1 \mathrm{mg}$ pronase $\mathrm{ml}^{-1}$ (Kaken, Toyko, Japan) for $10 \mathrm{~min}$ at $37^{\circ} \mathrm{C}$ and lysis with SDS. Clostridium cochlearium 17787 and montréan, and C. tetanomorphum $1772 \mathrm{C}, \mathrm{CIA}, \mathrm{A}, 2909$ and 288 were grown at $37^{\circ} \mathrm{C}$ for 6 to $11 \mathrm{~h}$ in PYG medium. The organisms were then harvested by centrifugation, suspended in $\mathrm{NaCl} / \mathrm{EDTA}$ solution, treated with $1 \mathrm{mg}$ lysozyme $\mathrm{ml}^{-1}$ for $20 \mathrm{~min}$ at $37^{\circ} \mathrm{C}$ and lysed with $3 \%(\mathrm{w} / \mathrm{v})$ SDS. Bacterial suspensions of strains $\mathrm{A}$ and $1772 \mathrm{C}$ in $\mathrm{NaCl} / \mathrm{EDTA}$ solution were heated at $60^{\circ} \mathrm{C}$ for $10 \mathrm{~min}$ before lysozyme treatment.

For the preparation of labelled DNA from C. tetani HA-47 and C. tetanomorphum 543, $\left[{ }^{3} \mathrm{H}\right]$ thymidine (10 $\mu \mathrm{Ci}$; Japan Isotope Association, Tokyo, Japan) was added to $100 \mathrm{ml}$ of the medium used for the isolation of unlabelled DNA of each strain. For the preparation of labelled DNA from C. cochlearium 17787, $\left[{ }^{3} \mathrm{H}\right]-$ thymidine $(10 \mu \mathrm{Ci})$ was added to $100 \mathrm{ml}$ medium containing (\%,w/v): trypticase (BBL), $3 \cdot 0$; brain heart infusion (Nissan, Tokyo, Japan), 0.3 ; glucose, 1.0 ; L-cysteine. HCl, 0.05; mineral salts (Holdeman \& Moore, 1975) and vitamins (Cummins \& Johnson, 1971). The organisms were incubated, treated and lysed by the procedure used for preparation of unlabelled DNA.

In all cases DNA was extracted from the lysate by the method of Marmur (1961).

Tests for DNA-DNA homology and the thermostability of DNA duplexes. These were performed as described previously (Nakamura et al., 1974).

Sugar fermentation tests. Sugars tested were adonitol, amygdalin, arabinose, cellobiose, dulcitol, aesculin, erythritol, fructose, galactose, glucose, glycerol, glycogen, inositol, inulin, lactose, maltose, mannose, mannitol, melezitose, melibiose, raffinosè, rhamnose, ribose, salicin, sorbitol, sorbose, starch, sucrose, trehalose and xylose. The basal medium was $\mathrm{P}$ medium $(\mathrm{pH} 7 \cdot 2)$ containing $(\%, \mathrm{w} / \mathrm{v})$ : proteose peptone no. 2 (Difco), 2.0; NaCl, 0.5; agar, 0.1; L-cysteine. $\mathrm{HCl}, 0.05$. Each sterile sugar was added to $3.5 \mathrm{ml} \mathrm{P}$ medium held in a small test tube to give $1 \%(\mathrm{w} / \mathrm{v})$, except for glycogen, inulin and salicin which were added at $0.5 \%(\mathrm{w} / \mathrm{v})$. Each tube was inoculated with $0.15 \mathrm{ml}$ of overnight culture in liver broth and incubated at $37^{\circ} \mathrm{C}$ for $7 \mathrm{~d}$. The $\mathrm{pH}$ values of cultures were measured with a $\mathrm{pH}$ meter. Fermentation of a sugar was read as positive when the $\mathrm{pH}$ difference $(\Delta \mathrm{pH})$ between cultures with and without sugar was more than 0.5 .

Other biochemical tests. Tests for reduction of nitrate, production of indole, digestion of coagulated albumen, production of $\mathrm{H}_{2} \mathrm{~S}$, haemolysis, growth at $0{ }^{\circ} \mathrm{C}$ and production of lecithinase were performed according to Nakamura et al. (1973). Digestion of casein and milk were examined by the method of Holdeman \& Moore (1975). Liquefaction of gelatin was examined by the methods of Nakamura et al. (1973) and Holdeman \& Moore (1975).

Analysis of fermentation products. Strains tested were incubated for $72 \mathrm{~h}$ in PY medium (Holdeman \& Moore, 1975). Fatty acids and alcoholic fermentation products were extracted from the cultures and detected by gas chromatography according to Holdeman \& Moore (1975), using a Nihon Denshi gas chromatograph model JCG-1100 (Nihon Denshi, Tokyo, Japan).

Spore morphology. A loopful of an overnight culture at $37^{\circ} \mathrm{C}$ in liver broth was streaked on PM medium $(\mathrm{pH} 7 \cdot 4)$ containing (\%, w/v): proteose peptone (Difco), 3.0 ; meat extract (Daigo), $1.0 ; \mathrm{NaCl}, 0.2$; agar, 2.0. The plate was incubated anaerobically under hydrogen at $37^{\circ} \mathrm{C}$ for $96 \mathrm{~h}$. Colonies were smeared, and stained by the method of Wirtz (1908) or by the Gram stain.

Isolation of C. tetani-like strains from horse faeces. About $5 \mathrm{~g}$ of each horse faeces sample was suspended in $10 \mathrm{ml}$ saline and heated at $60^{\circ} \mathrm{C}$ for $10 \mathrm{~min}$. A $1 \mathrm{ml}$ portion of the heated sample was transferred to $10 \mathrm{ml}$ 
Table 2. Polynucleotide sequence relationship among $C$. tetani and allied species

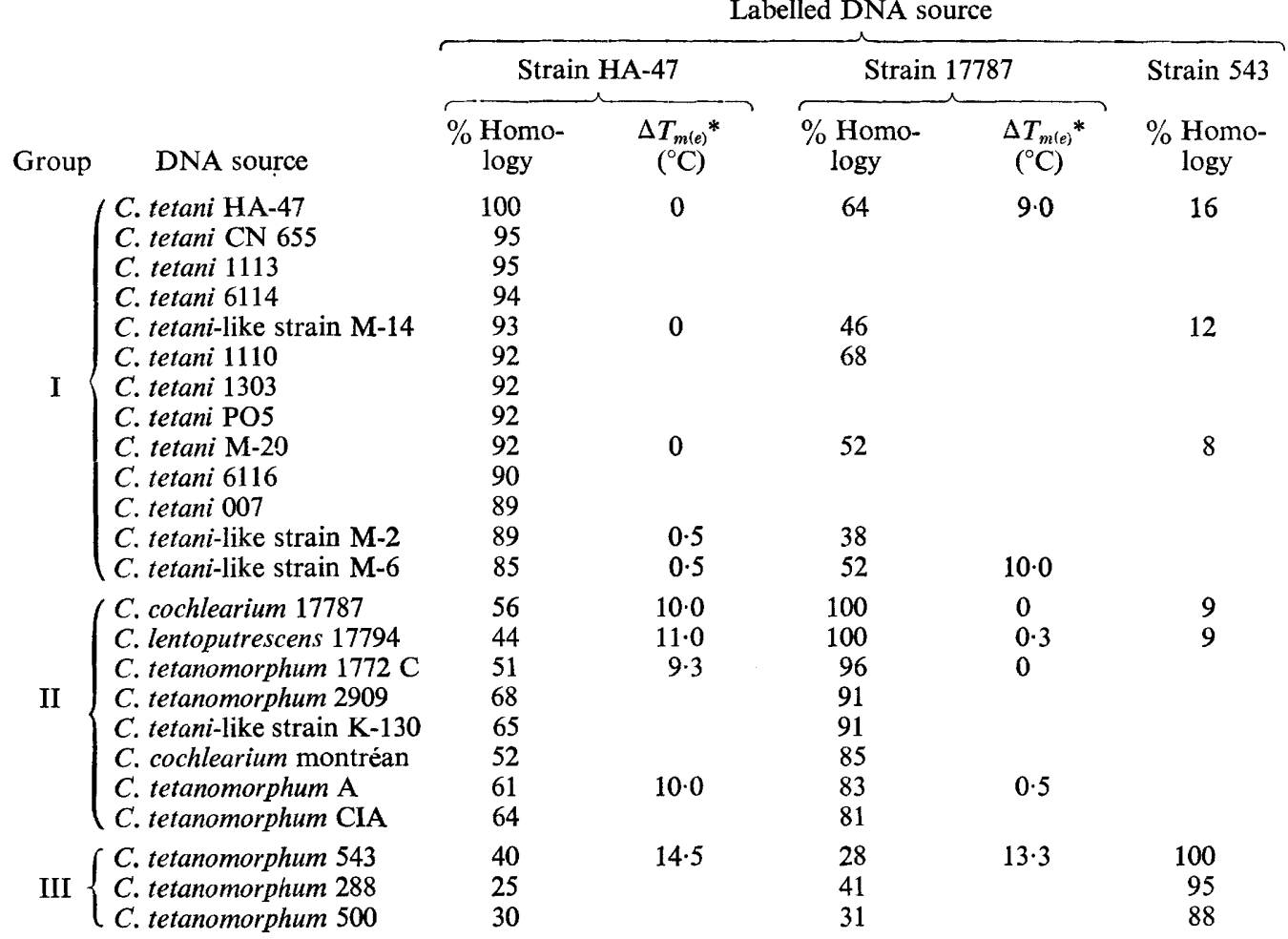

* $\Delta T_{m(e)}$ is the difference between the temperatures at which there is $50 \%$ dissociation of homologous and heterologous DNA duplexes.

$10 \%$ blood broth and incubated at $37^{\circ} \mathrm{C}$ for $3 \mathrm{~d}$. A loopful of $3 \mathrm{~d}$-old culture was streaked on a PM plate and incubated anaerobically under hydrogen at $37^{\circ} \mathrm{C}$ for $3 \mathrm{~d}$. Small translucent colonies were successively subcultured on the same medium.

Test for toxigenicity. This was performed using PII medium according to the methods of Sanada \& Nishida (1965) and Nishida et al. (1969).

\section{RESULTS}

\section{$D N A-D N A$ homology}

On the basis of tests for DNA-DNA homology, C. tetani and its related strains were separated into three genetically related groups (Table 2). All of 10 C. tetani strains and three non-toxigenic $C$. tetani-like strains were included in group I. Group II comprised C. tetanomorphum strains 1772 C, CIA, A and 2909, C. cochlearium strains montréan and 17787, and C. lentoputrescens type strain 17794. Group III comprised C. tetanomorphum strains 288, 500 and 543 ; these were distinct from the other two groups.

Further tests were performed to determine the thermostability of the duplexes formed between DNA from C. tetani HA-47 (group I) or C. cochlearium 17787 (group II) and DNA from some strains of groups I, II and III. The temperatures $\left(T_{m(e)}\right)$ at which $50 \%$ of the DNA duplexes between the group II strains and $C$. cochlearium 17787 dissociated were similar to those of homologous DNA duplexes of C. cochlearium $17787\left(\Delta T_{m(e)} 0\right.$ to $\left.0 \cdot 5\right)$. The $T_{m(e)}$ value for the DNA duplexes between C. tetanomorphum 543 (group III) and $C$. cochlearium 17787 was lower, by $13.3{ }^{\circ} \mathrm{C}$, than that of homologous DNA duplexes of C. cochlearium 17787. These data again confirmed that C. cochlearium, C. lentoputrescens 
Table 3. Biochemical properties for differentiation

Biochemical property
Class $A^{*}$
Fermentation of:
Glucose
Inositol
Galactose
Glycerol
Ribose
Xylose
Maltose
Cellobiose, fructose,
salicin, sorbitol
Mannose, sorbose
Liquefaction of gelatin:
$2 \%$ (w/v)
$10 \%$ (w/v)
Class $B^{*}$
Digestion of milk
Digestion of coagulated albumen
Growth at $0{ }^{\circ} \mathrm{C}$
Production of lecithinase
Reduction of nitrate
Digestion of casein
Production of indole
Production of H ${ }_{2} \mathrm{~S}$
Haemolysis of human blood
Production of toxin

Biochemical property

Group based on DNA-DNA homology $\dagger$

\begin{tabular}{ccc}
\multicolumn{3}{c}{ Group based on DNA-DNA homology $\overbrace{}^{+}$} \\
I & & II \\
& & \\
$8 / 13 \ddagger$ & $8 / 8$ & $3 / 3$ \\
$12 / 13$ & $0 / 8$ & $3 / 3$ \\
$0 / 13$ & $8 / 8$ & $3 / 3$ \\
$0 / 13$ & $7 / 8$ & $1 / 3$ \\
$0 / 13$ & $7 / 8$ & $3 / 3$ \\
$0 / 13$ & $3 / 8$ & $3 / 3$ \\
$0 / 13$ & $0 / 8$ & $3 / 3$ \\
& & \\
$0 / 13$ & $0 / 8$ & $3 / 3$ \\
$0 / 13$ & $0 / 8$ & $2 / 3$ \\
& & \\
$13 / 13$ & $6 / 8$ & $0 / 3$ \\
$12 / 13$ & $0 / 8$ &
\end{tabular}

$\begin{array}{rll}0 / 13 & 0 / 8 & 0 / 3 \\ 0 / 13 & 0 / 8 & 0 / 3 \\ 0 / 13 & 0 / 8 & 0 / 3 \\ 0 / 13 & 0 / 8 & 0 / 3 \\ 0 / 13 & 0 / 8 & 0 / 3 \\ 2 / 13 & 2 / 8 & 0 / 3 \\ 6 / 13 & 5 / 8 & 2 / 3 \\ 13 / 13 & 8 / 8 & 3 / 3 \\ 13 / 13 & 2 / 8 & 0 / 3 \\ 10 / 13 & 0 / 8 & 0 / 3\end{array}$

* Properties of class A are adopted for differentiation between groups I, II and III and those of class B for differentiation of the three groups from other associated clostridia.

$\dagger$ See Table 2.

\pm No. of strains positive/no. of strains tested.

and some strains of $C$. tetanomorphum were homologous and that two different kinds of strains were included in the species $C$. tetanomorphum.

\section{Biochemical properties}

Biochemical properties were re-investigated in a search for differential criteria corresponding to the genetic differences among the above-mentioned three groups and also for discriminating them from other associated species (Table 3). As the fermentation of most sugars by $C$. tetani and C. tetani-like strains was negative when read with a $\mathrm{pH}$ indicator, we measured the $\mathrm{pH}$ differences between cultures with and without sugar using a $\mathrm{pH}$ meter. Sugar fermentation tests were performed four times to confirm the validity of weak reactions.

Group I. Seven of these 13 strains fermented glucose and inositol. The $\Delta \mathrm{pH}$ between $7 \mathrm{~d}$ cultures with and without glucose or inositol reached 1.95 or 1.6 , respectively, as a maximum, but the final $\mathrm{pH}$ of these $7 \mathrm{~d}$ cultures with each sugar added only rarely fell below $6 \cdot 0$. These organisms fermented none of the remaining 28 sugars tested. Gas-chromatographic analysis of cultures in PY medium showed major peaks for butan-1-ol, acetic, propionic, butyric and lactic acids. The three non-toxigenic $C$. tetani-like strains were identified as $C$. tetani on a basis of DNA-DNA homology and biochemical properties.

Group II. No distinct differences in cultural and biochemical properties could be found among strains of this group, even though they were designated by different species names, 
i.e. C. cochlearium, C. tetanomorphum and C. lentoputrescens. Spores could be detected microscopically in all strains except strain 2909. Clostridium lentoputrescens 17794 produced abundant spores. Other strains produced very few. Although spores were spherical to oval in all strains, spherical spores dominated in strains 17794, K-130 and montréan.

All strains except 2909 and A attacked glucose, galactose, ribose and glycerol. The $\Delta \mathrm{pH}$ in $7 \mathrm{~d}$ cultures with and without glucose or galactose ranged between 0.6 (strain 2909) and $2 \cdot 1$ (strain K-130) or between 0.5 (strain $1772 \mathrm{C}$ ) and 1.1 (strain A), respectively. The final $\mathrm{pH}$ of $7 \mathrm{~d}$ cultures with glucose fell below 6.0 in all strains except 17787 and 2909 , but that of cultures with galactose did not. The $\Delta \mathrm{pH}$ in $7 \mathrm{~d}$ cultures with and without glycerol reached 1.5 in strain CIA, but the final $\mathrm{pH}$ of these cultures rarely fell below 6.0 . The $\Delta \mathrm{pH}$ in $7 \mathrm{~d}$ cultures with and without ribose reached 1.32 (strain CIA) and the final $\mathrm{pH}$, when $\Delta \mathrm{pH}$ was over 0.5 , fell below 6.0 . The $\mathrm{pH}$ of uninoculated $\mathrm{P}$ medium with ribose, however, dropped to about 6.7 , which was about 0.6 lower than that of uninoculated $\mathrm{P}$ medium with other sugars added.

Six strains of this group including the type strains of C. cochlearium and C. lentoputrescens liquefied gelatin.

Gas-chromatographic analysis of cultures in PY medium showed major peaks for acetic, propionic, butyric and lactic acids.

Group III. All of these three C. tetanomorphum strains fermented cellobiose, fructose, galactose, inositol, ribose, salicin, sorbitol and xylose, as well as glucose and maltose. None gave rise to $\mathrm{pH}$ values below 6.0 in the presence of sugars other than glucose, maltose, inositol and ribose. Mannose, sorbose and glycerol were fermented by some but not all strains. None of the remaining 17 sugars tested was fermented by the group III strains.

Gas-chromatographic analysis of cultures in PY medium showed major peaks for butan-1-ol, acetic, propionic and butyric acids.

\section{Isolation of group II strains}

Thirteen isolates from horse faeces, when tested for cultural and biochemical properties, were similar to the type strains of $C$. lentoputrescens or of $C$. cochlearium. Differential biochemical properties of these isolates are shown in Table 4. All of the isolates consistently and abundantly produced spherical spores, and seven of the 13 isolates exhibited weak but definite ability to liquefy gelatin in the test performed after $7 \mathrm{~d}$ incubation. It seems, therefore, justified to identify these isolates as $C$. lentoputrescens, but DNA-DNA homology studies on four of the isolates showed them to be genetically homologous with $C$. cochlearium type strain ATCC 17787 (Table 5).

\section{DISCUSSION}

Takahashi et al. (1967) demonstrated that two distinct groups of strains were included under the species name of $C$. tetanomorphum; one group comprised strains $1772 \mathrm{C}$, CIA, EC'1, A and NCTC 2909 and the other, strains NCTC 288, 500 and 543 and ATCC 15920 and 3606. The cultural and biochemical properties of the former group agree with those of C. tetanomorphum originally described as Pseudotetanus bacillus No IX by McIntosh et al. (1917). In the present tests for DNA-DNA reassociation, thermostability of DNA-DNA hybrids and biochemical properties, we demonstrated that $C$. tetanomorphum strains $1772 \mathrm{C}$, CIA, A and NCTC 2909 were genetically homologous with the C. cochlearium type strain ATCC 17787 as well as with $C$. cochlearium strains from the Pasteur Institute. Clostridium tetanomorphum strains NCTC 288, 500 and 543 were distinctly different from C. cochlearium and C. tetani strains in DNA-DNA homology as well as in cultural and biochemical properties. These strains were isolated from wounds in 1921 by M. Robertson (private communication from S. Lapage, NCTC) and have been used since then as the representative strains of this species. In the present study they attacked numerous sugars but the $\mathrm{pH}$ of the 
Table 4. Differential biochemical properties of isolates from horse faeces

$\begin{array}{lc}\text { Biochemical property } & \text { Isolates } \\ \text { Fermentation of: } & \\ \quad \text { Glucose, glycerol } & 13 / 13^{*} \\ \text { Ribose } & 12 / 13 \\ \text { Galactose } & 9 / 13 \\ \text { Inositol, xylose, maltose, cellobiose, fructose, } & \\ \quad \text { salicin, sorbitol, mannose, sorbose } & 0 / 13 \\ \text { Liquefaction of gelatin: } & \\ 2 \%(w / v) & 7 / 13 \\ 10 \%(w / v) ~ & 0 / 13\end{array}$

Table 5. Similarities between DNA from isolates from horse faeces and DNA from reference strains $C$. cochlearium ATCC 17787 and C. tetani HA-47

$\%$ Homology with DNA from:

Organism

C. tetani HA-47

C. cochlearium ATCC 17787

Isolate $\mathrm{H}-4$

Isolate $\mathrm{H}-8$

Isolate $\mathbf{H}-7$

Isolate no. 20

$\begin{array}{cc}\text { ATCC } 17787 & \text { HA-47 } \\ 64 & 100 \\ 100 & 56 \\ 92 & 59 \\ 92 & 59 \\ 92 & 59 \\ 91 & 60\end{array}$

$7 \mathrm{~d}$ cultures did not fall below 6.0 in the presence of sugars other than glucose, maltose, inositol or ribose.

In the carbohydrate fermentation, we used $\mathrm{pH}$ measurement whereas most diagnostic and identification studies involve $\mathrm{pH}$ indicators. Thus, many of the reactions reported here as positive would be negative using $\mathrm{pH}$ indicators as the $\mathrm{pH}$ frequently did not fall below 6.0. Fermentation results of this group, therefore, agree with the original description of C. tetanomorphum (Bulloch et al., 1919). Although Fildes, together with McIntosh et al. (1917), isolated different kinds of non-toxigenic C. tetani-like strains which were later established as C. tetanomorphum and C. cochlearium by their colleagues (Bulloch et al., 1919), Fildes (1927) stated that the two species as well as $C$. lentoputrescens were not worthy of separation, being at best merely representatives of the saccharolytic extreme on the one hand or proteolytic on the other. Our present study has verified the validity of Fildes' viewpoint on the relationship between $C$. cochlearium and some strains of C. tetanomorphum and has also revealed that the type strain and our isolates of $C$. lentoputrescens are genetically homologous with a type strain of $C$. cochlearium. As the two species' names $C$. tetanomorphum and C. cochlearium were simultaneously established by the same authors (Bulloch et al., 1919), neither has precedence. Clostridium tetanomorphum strains in group II that are genetically homologous with the type strain of $C$. cochlearium should be renamed as $C$. cochlearium and the species name C. tetanomorphum kept for strains NCTC 288, 500 and 543 as well as for strains ATCC 3606 and 15920.

One of the main criteria differentiating $C$. lentoputrescens from $C$. cochlearium is the ability to liquefy gelatin. Using $2 \%(\mathrm{w} / \mathrm{v})$ gelatin or the method of Holdeman \& Moore (1975), we found that most C. cochlearium strains attacked gelatin. Hartsell \& Rettger (1934) suggested the identity of $C$. lentoputrescens with $C$. cochlearium from various authors, when they proposed the name $C$. lentoputrescens. The species name $C$. lentoputrescens should be abandoned as a later synonym of $C$. cochlearium. All of our isolates previously designated as C. lentoputrescens were obtained from horse faeces samples. Although Jawetz et al. (1976) 
stated that $C$. tetani could frequently be isolated from horse faeces and Smith (1975) referred to $C$. tetani in horse manure, we have seldom isolated $C$. tetani strains from horse faeces in spite of the frequent presence of $C$. tetani-like spores in the samples. Fildes' method (Fildes, 1927) was ineffective for isolating anaerobes with $C$. tetani-like spores, since they did not exhibit swarming.

The name C. pseudotetanicum (Prévot) comb. nov. Smith \& Hobbs 1974, has been listed in the eighth edition of Bergey's Manual. Nakamura et al. (1973), however, demonstrated that a Plectridium pseudotetanicum strain tested was in agreement with C. tertium in its cultural and biochemical properties.

Another $C$. tetani-like species fermenting glucose and maltose, C. tetanoides (Adamson) Hauduroy 1937, is described in the seventh edition of Bergey's Manual. No reliable strains of C. tetanoides or of C. pseudotetanicum are available, however, and we feel justified in not yet recognizing these species as definite entities.

\section{REFERENCES}

Bergey, D. H., Harrison, F. C., Breed, R., Hammer, B. W. \& Huntoon, F. M. (editors) (1923). Bergey's Manual of Determinative Bacteriology, 1st edn, pp. 330-331. Baltimore: Williams \& Wilkins.

Breed, R. S., Murray, E. C. D. \& Smith, N. R. (editors) (1957). Bergey's Manual of Determinative Bacteriology, 7th edn, pp. 677-678. Baltimore: Williams \& Wilkins.

Bullock, W., Bullock, W. E., Douglas, S. R., Henry, H., MCIntosh, J. \& O'Brien, R. A. (1919). Report on the anaerobic infections of wounds and the bacteriological and surgical problems arising therefrom. Medical Research Council Special Reports no. 39, 41-42.

Cummins, C. S. \& Johnson, J. L. (1971). Taxonomy of the clostridia: wall composition and DNA homologies in Clostridium butyricum and other butyric acid-producing clostridia. Journal of General Microbiology 67, 33-46.

FILDES, P. (1927). Tetanus-III. Non-toxic variants of C. tetani. British Journal of Experimental Pathology 8, 219-226.

Hartsell, S. E. \& Rettger, L. R. (1934). A taxonomic study of 'Clostridium putrificum' and its establishment as a definite entity-Clostridium lentoputrescens, nov. spec. Journal of Bacteriology 27, 497-515.

Holdeman, L. V. \& Moore, W.E. C. (editors) (1975). Anaerobe Laboratory Manual, 3rd edn. Blacksburg, Va: Virginia Polytechnic Institute and State University.

Jawetz, E., Melnick, J. L. \& AderberG, E. A. (1976). Review of Medical Microbiology, 12th edn (Maruzen Asian edn), p. 188. Tokyo: Maruzen.

McIntosh, J., Bulloch, W. \& Fildes, P. (1917). The classification and study of the anaerobic bacteria of war wounds. Medical Research Council Special Reports no. 12, 12-13, 32-33.
MARMUR, J. (1961). A procedure for the isolation of deoxyribonucleic acid from microorganisms. Journal of Molecular Biology 3, 208-218.

Nakamura, S., Shimamura, T., Hayase, M. \& NishidA, S. (1973). Numerical taxonomy of saccharolytic clostridia, particularly Clostridium perfringens-like strains; description of Clostridium absonum sp. n. and Clostridium paraperfringens. International Journal of Systematic Bacteriology 23, 419-429.

Nakamura, S., Shimamura, T., Hayashi, H. \& Nishida, S. (1974). Reinvestigation of the taxonomy of Clostridium bifermentans and Clostridium sordellii. Journal of Medical Microbiology 8, 299309.

Nishida, S., Y Amagishi, T., TAmai, K., SANada, I. \& TAKAHASHI, K. (1969). Effects of heat selection on toxigenicity, cultural properties, and antigenic structures of clostridia. Journal of Infectious Diseases 120, 507-516.

SANADA, I. \& NishidA, S. (1965). Isolation of Clostridium tetani from soil. Journal of Bacteriology 89 , 626-629.

Smith, L. DS. (1975). The Pathogenic Anaerobic Bacteria, 2nd edn, p. 180. Springfield, Ill.: Charles C. Thomas.

SмIтH, L. DS. \& Hoввs, G. (1974). Clostridium. In Bergey's Manual of Determinative Bacteriology, 8th edn, pp. 551-572. Edited by R. E. Buchanan \& N. E. Gibbons. Baltimore: Williams \& Wilkins.

Takahashi, K., TAmaI, K. \& NishidA, S. (1967). Taxonomic studies on Clostridium tetanomorphum. Medicine and Biology 75, 81-85 (in Japanese).

WIRTZ, K. (1908). Eine einfache Art der Sporenfärbung. Zentralblatt für Bakteriologie, Parasitenkunde, Infektionskrankheiten und Hygiene (Abteilung I, Originale A) 46, 727-728. 